Svitlana Pokhylko,

Ph.D, Sumy State University, Ukraine

D ORCID ID, 0000-0001-5739-2795

email: s.pokhylko@finance.sumdu.edu.ua

Monika Grabowska,

Ph.D., Wroslaw University of Economics and Business, Poland

ORCID ID, 0000-0001-9627-0221

email: monika.grabowska@ue.wroc.pl

Yurii Nikitin,

Sumy State University, Ukraine

Correspondence author: s.pokhylko@finance.sumdu.edu.ua

\title{
NECESSARY TRANSFORMATION OF ADMINISTRATION FOR FAMILY PHYSICIANS PRACTICE
}

Abstract. This paper considers the internationally leading models in administration work of family physicians, such as traditional care in outpatient clinics, disease control programs, and human-centered primary health care. The authors noted that the Ukrainian model of «human-oriented health care» is being confidently formed under the health care modernization and EU integration process. The authors found the reducing number of hospitalizations of the catchment population; decreasing mortality at home with cardiovascular disease, tuberculosis, diabetes; reducing the congenital malformations of children undetected during their mothers' pregnancy. In addition, the study detected the growth of the visit number of the catchment population to the healthcare facilities for preventive purposes; an expanding the nursing of the number of one-year-old children; no cases of child deaths at home, etc. The findings showed that the process of administrative control and evaluation of the effectiveness of family physicians should be based on clearly defined criteria. Each head of the health care facility could set their own requirements for the effectiveness of primary care physicians. The specification of certain indicators for assessing the effectiveness of the family physicians covers the number, density, age, and sex of the population, morbidity, geographical and other characteristics. However, the lack of uniform requirements for administrative control and evaluation of the work of family physicians complicates the process of administering the work of primary care physicians, which needs to be further addressed. The article aims to analyze the effectiveness of the administration of family physicians in the Municipal non-profit enterprise of Konotop City Council "Konotop Municipal Hospital». The main problems and directions of improving the efficiency of administration of family physicians were highlighted. It was established that the most significant shortcomings were the absence of a website; insufficient number of practicing family physicians; dissatisfaction with wages; insufficient level of logistics; insufficient level of practical training of young specialists, etc. Family physicians also noted difficulties in the transition from working with paper documents to digital ones and weak Internet and poor performance of relevant servers. In turn, that affects the entire process of family physicians from the moment of registration (via the Internet or by phone) to the issuance of electronic prescriptions for medicines or sick leaves. Based on the study results, several recommendations were made to family physicians and hospital administration to increase their work efficiency.

Keywords: personnel administration, primary care setting, medical care, family physicians, administration efficiency.

Introduction. The main priority of modern Ukraine's state policy is to preserve and strengthen the population's health. Nowadays, healthcare institutions attract more attention and need reformation. An essential indicator of the effectiveness of administrative and managerial activities of healthcare institutions is the public's trust in them. The state policy in domestic health care is focused on acquiring the most significant effect from the existing human resources. Administrative management in health care involves

Cite as: Pokhylko, S., Grabowska, M., \& Nikitin. Yu. (2021). Necessary Transformation of Administration for Family Physicians Practice. Health Economics and Management Review, 3, 48-64.

48 http://doi.org/10.21272/hem.2021.3-05 
the management of financial, labor, and material resources. The main goal of health management is to reduce society's losses from morbidity, disability, and mortality. Due to the primary healthcare reformation, healthcare administrations have gained more autonomy from the central government. Therefore, they endeavor to minimize costs, identify financial reserves, increase revenue from paid medical services. In turn, the defined goals require improving methods of administration of primary healthcare institutions, their comprehensive statistical and financial control, optimization of the treatment process, etc. Thus, the family physicians' administration system needs detailed consideration in light of reorganization changes.

This paper aims to theoretically substantiate the process of administration of family doctors, determine the main directions, and find ways to improve the efficiency of the administration process at the primary level.

Literature Review. This study employed bibliometric analysis to determine the relevance of the issue of family physician administration worldwide. The findings allowed identifying the terms and study fields in Scopus's scientometric database regarding the research object. The search was conducted by the keyphrase «Administration of the family doctor's work» to find the most relevant publications. As a result, 23 documents were found. Compared to the search results by the phrase «family doctor» (about 1800 publications), this is a small number of works. Thus, the obtained results evidence that this area is in its infancy. Therefore, there are many challenges to be addressed in the future (Figure 1).

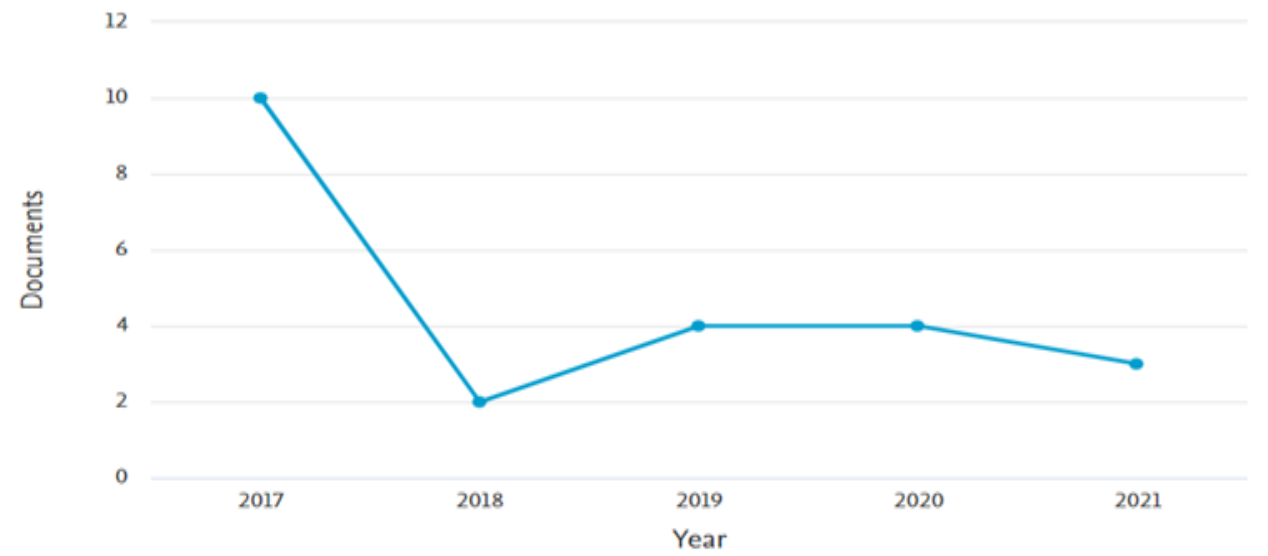

Figure 1. The number of publications in the Scopus database from 2017 to 2021 Sources: developed by the authors.

From early 2000 to 2017 (including), in the view of the begging the healthcare reform implementation, the world community had increased interest in administrating the family physicians' work (10 papers). From 2017 up to and including 2018, there was a decline in the publication activity on the research topic. In turn, the lowest number of publications was in 2018 (2 documents). Further, from 2018 and up to the present, there is a growing tendency in the publication activity (3-4 papers).

In geography (Figure 2), most authors (five) are from the USA. Then, three authors are from Great Britain, two from Italy and two from the Russian Federation, by one author from India, Germany, China, Japan, etc. 


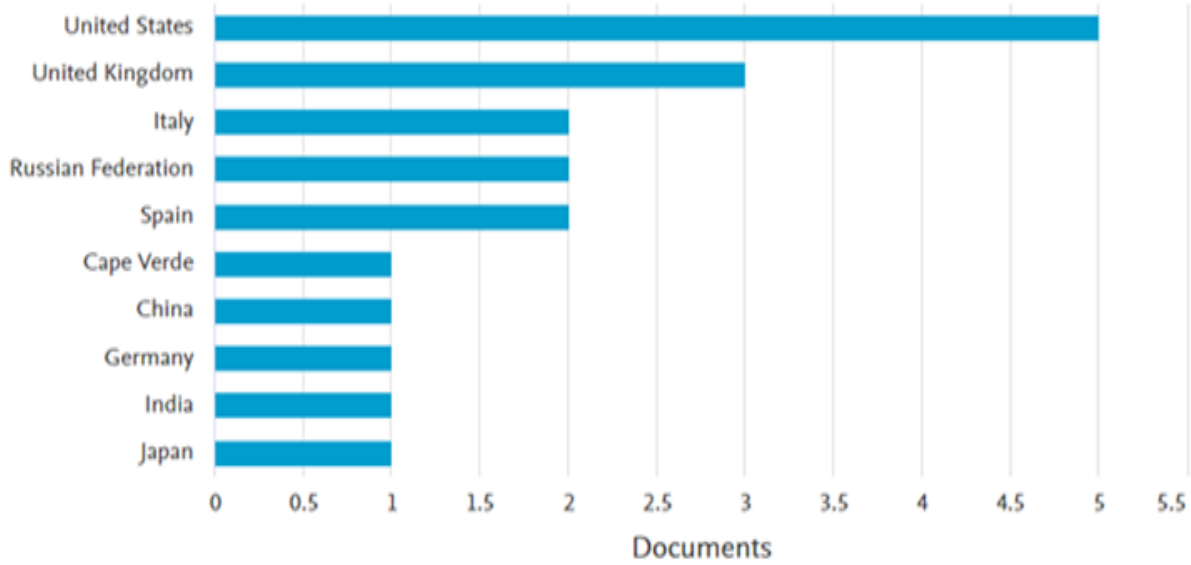

Figure 2. The number of publications in the Scopus database by countries Source: developed by the authors.

Regarding the field of research, most publications belong to the medical research area $(65.6 \%)$. Social sciences and biochemistry are the next.

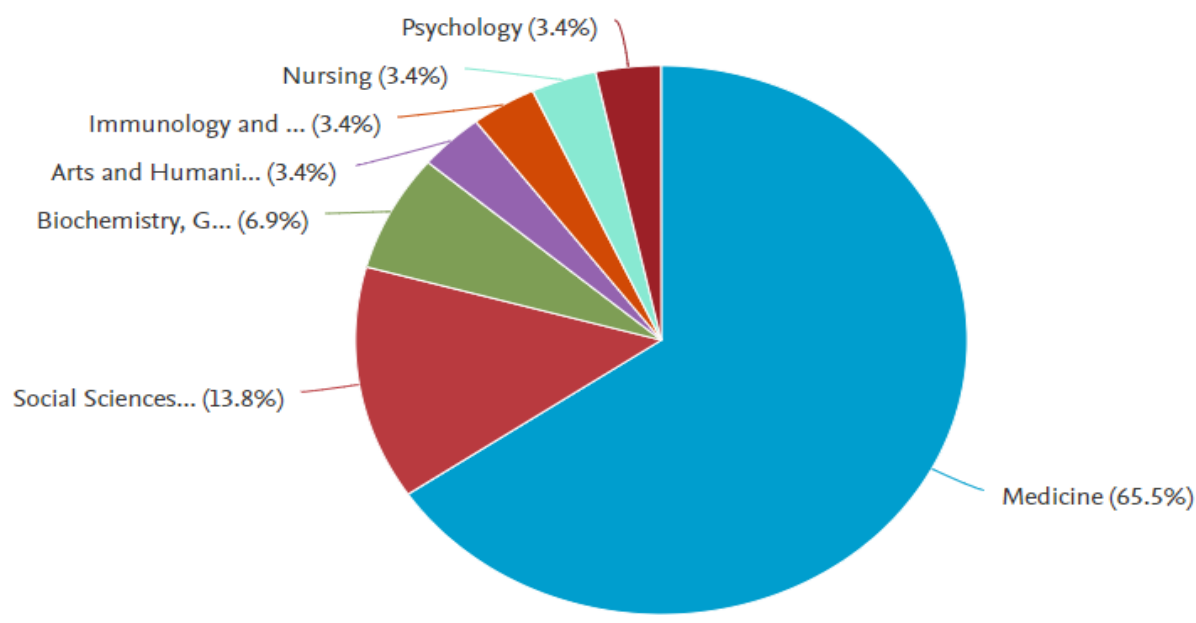

Figure 3. The number of publications in the Scopus database by research areas Source: developed by the authors.

Many domestic and foreign scientists such as Tkachenko V., Chopey I., Bilynska M., Voronenenka Yu., Golunov A., Furtak I., et al. significantly contributed to the study of family medicine. However, it has still required a more detailed analysis of the administration of family medicine and prospects for its development in Ukraine. The selection of highly qualified administrative and managerial staff is acute due 
to the reforming of the health care system of Ukraine. Nowadays, the basis of successful hospital management rests on special organizational skills for the skills of heads. Noteworthy here, they must be successful managers to be responsible for organizing and conducting successful administrative work in hospitals.

The process of administering the result of family physicians is essential in the management system of the healthcare institution. There are many scientific works of modern theorists and practitioners such as Andrushkiv B., Besedin M., Vasylenko V., Grabovsky V., Dumansky Yu., Klymenko P., Kuzmin O., Nagaev V., Synyachenko O., Uzunov V., Shevchenko V. et al. devoted to administration issues of family physicians work. However, these papers have still had a gap in exploring the administration of family physicians at the primary level of healthcare. Thus, Voronenko Yu., Grabovsky V., Dumansky Yu., Klymenko P., Synyachenko O., Stefanyshyn L., Flomin Yu. agreed the administration is a process of subordinated activity of the administrative department in organizing and controlling the dependent entities.

The study, Hashim (2016) showed that the principles of general practice and family medicine are the core characteristics of the specialty. The above principles cover the view of the individual and the context of the disease, including family, culture, and society; continuity of relationships (an interpersonal relationship of trust and respect between family physicians, patients, and their families formed throughout life); reflexive attentiveness-awareness of physicians of their thoughts and emotions, which manifests itself as a sense of presence and attention to themselves and others; and lifelong learning (the commitment to personal and professional development through participation in educational activities and practical research, lead to better results for patients).

De Maeseneer (2017) noted that Lord Bertrand Dawson proposed three hierarchical levels of care (primary, secondary, and tertiary) in the UK in early 1920. Firstly, he identified "primary care» as the most basic level of a structured health care system. In the Netherlands, there was a strong development of general practice/family medicine in the 1950s. In early 1956, the famous Woudschoten conference finally defined the functions of the family physicians to take responsibility for constant, comprehensive, and personal care for the health of individuals and families. In turn, care should focus on preventing and treating family health disorders (if possible) (triple task: cure, rehabilitate, and prevent).

Abrams et al. (2017) emphasized the need to create cycles of free flow of electronic information about patients' health to simplify the process of administering a family physician.

While Love et al. (2012) identified that adopting electronic healthcare records (EHR) was a national priority in the USA. Besides, well-designed EHRs could improve family medicine's quality and safety. However, family physicians are reluctant to implement EHR because of financial restrictions, inconvenience, and concerns about the unintended consequences of possible errors. Thus, an administrative problem needs to be addressed to improve health care quality.

Apaydin (2020) noted that primary care physicians faced an increasing amount of administrative work, namely: making entries in electronic medical records, resolving insurance issues, and providing test results. They are not taking into account the personal reception of patients. The author emphasized that the problem with the relationship between family physicians and administrative work is primarily that most physicians did not imagine that administrative work would be part of their functional responsibilities. Therefore, it is necessary to reduce the administrative work of primary care physicians in the future. Therefore, the administrative component is in dire need of reform.

Studies by Quinn et al. (2009) determined the need for quality administration of family physicians as the future of affordable and high-quality healthcare in America.

The current publications show that primary care physicians are dissatisfied. They do not recommend this field to students because of electronic medical records, the inefficiency of office practice, lack of teamwork, pressure on time during office visits, lack of control over the workplace, low career perspectives, 
etc. Respondents reported moderate and severe problems with isolation (17\%), stress at work (31\%), and dissatisfaction (27\%).

Methodology and research methods. This research applied the general scientific methods as the method of theoretical comparison (on the comparative characteristics of the administration of family physicians in different countries), generalization and grouping, analysis and systematization, a bibliometric analysis of publications indexed in the scientometric database Scopus.

Results. The concept of «administration» in health science. In reforming the health care system of Ukraine, the issue of selection of highly qualified administrative and managerial staff became acute. According to the current trends, successful hospital management rests on special organizational skills for managers. The new managers of the healthcare system would be responsible for organizing and conducting successful administrative work in hospitals.

Vasylenko and Shostka (2003) defined the administrative department as people in managerial positions, while the administration is a process of their professional activity.

Bayeva (20017) supported the opinion of Henri Fayol that administration ensures the collective work in achieving goals under anticipation, planning, organization, motivation, and control.

There are six main models of administration classified by goals, motivation, framework administration, delegation-based administration, participatory administration, and business administration (Vynogradskiy and Shkanova, 2009).

A management system characterizes administration by objectives with a given purpose in decentralized management. The main focus of this model is on the motivation of human resources and the development of cooperation (Vynogradskiy and Shkanova, 2009).

Administration by motivation. This model examines employees' needs, interests, and personal goals. In developing this model, the administration guidelines are aimed at developing human resources, the choice of an effective model of motivation (Vynogradskiy and Shkanova, 2009).

The framework administration model allows employees to make independent decisions within the previously established framework. This model creates conditions for employees, develops independence and responsibility, forms the growth of job satisfaction, develops corporate leadership, etc. (Vynogradskiy and Shkanova, 2009).

Delegation-based administration provides the task delegation to a lower level. This model differs from the model of framework administration since it is characterized by a clear statement of tasks, a definition of the boundaries of decision-making, a division of responsibilities for actions and results (Voronenko and Pashchenko, 2011).

Participatory administration. An employee from the administrative department becomes a subject of administration, who makes decisions independently. Under this management model, the organization's employee realizes their needs for self-expression, recognition, participation (Vynogradskiy and Shkanova, 2009).

Entrepreneurial administration is characterized by the development of entrepreneurial activity within the organization. Preference is given to a democratic government (Voronenko and Pashchenko, 2011).

Personnel administration is a part of the enterprise's labor resources management. The process of administration activity is characterized by its specific features and patterns.

Administration of medical staff includes management of financial resources of the healthcare institution; management and control of medical activities; management of healthcare personnel in strategic planning, ensuring the development of the healthcare institution. The administration process in health science has specific functions (Fig. 4). 


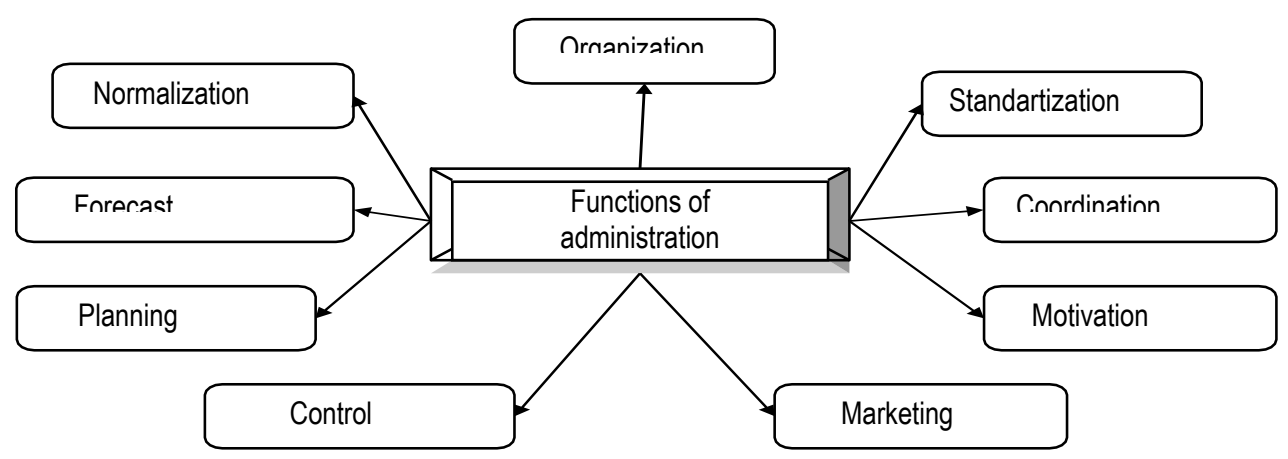

Figure 4. Administration features

Sources: develiped by the authors based on (Danko, 2017; Yeroshkina et al., 2012).

The main tasks of administering the work of medical staff are; providing healthcare institutions with personnel, ensuring the rational placement of qualified specialists and their promotion, effective use of the labor potential of the healthcare institution, etc. (Rovenska and Sarzhevska, 2019).

Besides, the choice of work principles is the particular importance in the administration of medical staff. Noteworthy, to highlight the following principles of medical staff administration: science, democratic centralism, planned character, "the first-person», a combination of unity of command, unity of management, selection, choosing, and placement. It is worth noting that the administration system has two links as managed and managing. Managers are commonly referred to as administration subjects, and those who are managed are called objects of administration. Thus, the administration subject is the leading link in the management system, which has a targeted influence on the administration objects. In turn, the object of administration is the controlled link of the system, which perceives the controlling influence of the subject of administration (Prokopec and Todoriko, 2020).

Administration of the health care organization is a complex process based on the choice of optimal solutions, considering both the internal problems of the organization and the changing economic and political situation in the country and the world (Grabovskiy and Klymenko, 2014). For optimal administration, it is necessary to rely on the several fundamental principles of a particular process as purposefulness, legal protection of administrative and managerial decisions; management optimization; centralization and decentralization of management; delegation of powers.

The administrative-managerial style is a unique way of carrying out administrative activities depending on the personality of the head. In many respects, the defined style is formed under the influence of the formed relations between the head and staff concerning the acceptance and realization of administrative and managerial decisions. According to Bilynska and Popchenko (2017), the most common administrative and managerial styles are authoritarian, liberal, democratic, and dynamic.

In the healthcare institution, it is essential to have management methods, which are defined as ways and means of influencing the head of the health care organization or its departments to more effectively use available resources to solve its tasks. The methods of health care management are as follows:

- organizational and managerial (allow compensating for inaccuracies in planning, respond quickly to changing situations and, making adjustments, bring the object of management to new parameters through directives, orders, instructions, directives, resolutions, orders, etc.);

- economic and mathematical (include economic analysis of the healthcare organization, methods of planning and forecasting, statistical analysis, etc.); 
- socio-psychological (a set of means of influencing the team, the processes taking place in the team and individual employees, etc.);

- public or collective (provide for the democratization of management, i.e., increasing the participation of employees in the performance of administrative functions) (Saphonov and Borsch, 2019).

The most crucial link in the administration system is the development and implementation of administrative decisions. The administrative and managerial decision is a directive act of purposeful influence on the administration object. It is based on reliable data analysis and contains an algorithm for achieving the goal. The head of the healthcare institution makes administrative and managerial decisions based on the analysis of the existing situation choosing the optimal (from many alternatives) decision to achieve this goal. The head makes administrative and managerial decisions within the powers granted to him considering current legislation (Pariy, 2015).

The administrative and managerial decisions are classified by:

- decision implementation time (strategic, tactical, operational, routine);

- the degree of participation of the team, individual specialists (individual, collegial);

- the content of the management process (medical-organizational, administrative-economic, sanitary-preventive, etc.);

- $\quad$ style and characteristics of the leader (intuitive, impulsive, inert, risky, cautious, etc.) (Prokopec and Todoriko, 2020).

The administrative and managerial decisions should meet the following requirements:

- target orientation (full compliance with the goals and objectives);

- justification (the need to make the particular decision);

- $\quad$ targeting (by performers);

- consistency (consistency with previous decisions);

- legitimacy (compliance with legal acts and regulations);

- efficiency (achieving maximum results with minimum costs);

- specificity in time, space, and timeliness (adoption at the very moment when the implementation of the decision could lead to the desired result) (Smiyanov et al., 2013).

Administrative and managerial decisions could be committed to writing, electronic, or transmitted orally. The adopted administrative decision is a directive act binding. In healthcare institutions, it could be taken in the form of orders, directives, recommendations, etc. (Shevchenko, 2016).

Thus, the administration of medical staff is not a scientific and theoretical abstraction, which is only indirectly related to the practice of healthcare organizations. It is an important component of its successful operation, which allows to coordinate the institution's work, create a strong team, and increase medical services quality.

The administration of any medical practice, including the work of family physicians, is clearly regulated by state legal documents, such as the Constitution of Ukraine, Laws of Ukraine, resolutions of the Cabinet of Ministers of Ukraine, orders of the Ministry of Health of Ukraine and other ministries.

The main orders of the Ministry of Health of Ukraine in primary healthcare are order № 503 from 19.03.2018 «On approval of the Procedure for selection of a doctor who provides primary care and forms of declaration on the selection of a doctor who provides primary care», № 504 of 19.03.2018 «On approval of the Procedure for providing primary medical care».

The reform of primary health care began in 2018 with the creation of the National Health Service of Ukraine (NHSU), electronic eHealth, and the connection of primary care physicians. The current legislation stipulates the rights and responsibilities of the healthcare institution director, his deputy (according to the Order of the Ministry of Health of Ukraine №1977 as of 31.10.2018), family physicians, etc. According to current legislation, family physicians may work in public and private healthcare institutions. 
The following state documents guide the work of the National Health Service of Ukraine as the Laws of Ukraine №2168-VIII as of 19.10.2017 «On state financial guarantees of medical services to the population» and №2233-VIII as of 07.12.2017 «On Amendments to the Budget Code of Ukraine»; Orders of the Ministry of Health of Ukraine №503 and №504 as of 19.03.2018, №148 as of 26.01.2018 «On approval of the Model table of material and technical equipment of health care facilities and individuals entrepreneurs who provide primary care»; Resolution of the Cabinet of Ministers of Ukraine №1124 as of 27.11.2019 «On approval of the Procedure for the implementation of state guarantees of medical care for the population under the program of medical guarantees in 2020»; №1073 as of 27.11 .2019 «Some issues of public health care contracts», №391 as of 28.03.2018. "On approval of requirements to the provider of medical services, with whom the main managers of budget funds enter into contracts for medical care», №65 of 5.02.2020 «Some issues of implementation of the state healthcare guarantee program in 2020», etc.

Nowadays, the creation of primary health care (medical and sanitary) centers is being promoted following the order of the Ministry of Health of Ukraine №801 as of 29.07.2016. These centers are created by the decision of local authorities and undergo the procedure of licensing and accreditation of family physicians of the institution. The director of the primary health care centers performs all necessary administrative work to improve its functioning and competitiveness. Treatment of the population in the primary health care centers is carried out at the expense of budget funds and the National Health Insurance Fund. Registration of private healthcare practice could occur after the state registration of a private individual under Classification of Business Activities 86.21 «General medicine». The owner of an individual entrepreneur must perform all the functions of the director of the healthcare institution.

Besides, there are three basic models of healthcare delivery. The head of each healthcare institution could independently choose the appropriate system for his institution. In line with the WHO terminology, one of the most popular strategies is the «human-centered care» strategy covering comprehensive treatment such as rehabilitation and prevention services. Table 1 presents the comparative characteristics of «human-centered care» and traditional models.

According to the analysis, it is noted that in Ukraine, the model of «human-oriented medical care» is being confidently formed. Changes in the legal framework and processes of changing the strategy of primary medicine show that the Ukrainian health care system undergoes modernization and integrates into the European standards.

Table 1. Characteristics of primary health care models

\begin{tabular}{|c|c|c|}
\hline $\begin{array}{c}\text { Traditional care assistance } \\
\text { ambulatory - outpatient } \\
\text { department }\end{array}$ & Disease control program & $\begin{array}{l}\text { Human-centered primary } \\
\text { health care }\end{array}$ \\
\hline $\begin{array}{l}\text { Priority is given to the disease and its } \\
\text { treatment. } \\
\text { Relationships are limited by visits. } \\
\text { Occasional medical care. } \\
\text { Responsibility is limited to providing } \\
\text { effective, safe medical prescriptions } \\
\text { and recommendations during the visit. } \\
\text { Patients act as consumers of the } \\
\text { services they purchase. }\end{array}$ & $\begin{array}{l}\text { Emphasis on priority disease. } \\
\text { The program limits the relationship. } \\
\text { The program provides measures to } \\
\text { combat the disease. } \\
\text { Responsibility for achieving disease } \\
\text { control targets in the target } \\
\text { population. } \\
\text { Population groups are target } \\
\text { objects for disease control } \\
\text { measures. }\end{array}$ & $\begin{array}{l}\text { Emphasis on health needs. } \\
\text { Long-term individual relationships. } \\
\text { Comprehensive and continuous } \\
\text { assistance according to individual } \\
\text { needs. } \\
\text { Responsibility for the health of all } \\
\text { members of the community } \\
\text { throughout life. } \\
\text { Responsibility for influencing the } \\
\text { determinants of health disorders. } \\
\text { People are involved as partners in } \\
\text { addressing health issues (both their } \\
\text { own and local health)громади). }\end{array}$ \\
\hline
\end{tabular}

Sources: developed by the authors based on (Bayeva, 2007). 
Features of the family physicians work abroad and in Ukraine. Singapore's health care system ensures the population's health through health prevention programs and the promotion of healthy lifestyles. Primary health care includes preventive health care and health education. Private practitioners provide $80 \%$ of primary health care, and public primary health care provides the rest. Singapore has a network of 18 outpatient clinics and 2000 private medical clinics. Each clinic is subsidized by a single medical center, providing outpatient treatment, follow-up treatment for discharged patients, immunization, medical examinations, education, etc. The elderly could receive additional assistance under the PCPS program (for those who cannot come to the clinic). Thus, in the Singapore health care system, the provision of primary care to the population is entrusted to the private sector, which has state support (Mukhambekov, 2012).

In contrast to Singapore's health care system, there is Spanish. A patient in Spain does not have the right to choose a doctor - whether a therapist, family doctor or another specialist. Instead, the patient is attached to one of the therapists working at the citizen's place of residence. If there is a need for specialized medical care, the therapist refers the patient to one of the doctors on the list. As a result of such a system, the following phenomenon has emerged. To change doctors or find specialized healthcare institutions without long queues, patients change their place of residence. The length of queues varies from region to region, but the problem of «waiting lists» is widespread. On average, it is necessary to wait for an appointment with a specialist for at least 65 days. Thus, such a system is not successful enough and limits people's rights to quality and emergency medical care (Mukhambekov, 2012).

Independent services represent the USA healthcare system with three levels: family medicine, hospital care, and the public health system. Family medicine is a fairly developed structure. Family physicians examine and observe patients and, if necessary, refer them to specialized specialists or the hospital. Doctors receive payment directly from patients. As a rule, the family doctor has his own office or cooperates with other specialists. In the USA, the concept of outpatient care includes the provision of services without patient hospitalization. Nursing organizations provide home treatment. Besides, it is usually ordered by doctors. The private sector of outpatient care is represented by personal physicians (internal and family medicine specialists, pediatricians), narrow specialists, nurses, and other medical staff. Payment for their work is made personally by patients. Thus, the USA health care system is private and built on the principles of a market economy and actively branched insurance medicine system. However, it extends mainly to hospitals and clinics (Mukhambekov, 2012).

In turn, the Ukrainian healthcare system allows every citizen to choose the family physician and sign a contract with him. The number of visits to the doctor is unlimited. Each visit is free. In addition, there is a list of free services, which includes preventive examinations, vaccinations, basic tests (general blood test, electrocardiogram, blood glucose test, etc.), palliative care, etc. In addition, the family doctor prescribes the necessary prescription drugs, including from the program «Available medicines» (the state pays more of the cost of medicines under this program).

Family medicine in Ukraine may be public and private ownership. It stands to note that the state standards regulate the work of family doctors in both cases. The person could make an appointment with a family doctor via the Internet or phone. If necessary, and at the doctor's discretion, the doctor could visit patients at home. With the referral of a family doctor, the patient could receive free specialized medical care and pass narrowly specialized tests, the list of which is presented in the order of the Ministry of Health of Ukraine №504 as of March 19, 2018. The National Health Insurance Fund transfers funds for the provision of primary health care to each person to the account of the medical institution where the family doctor works, with whom the person has a contract.

Thus, considering all of the above, the primary health care system in Ukraine is being modernized and trying to consider all the population's medical needs. 
The main indicators of administrative control over the effectiveness of the process of family doctors. The process of administrative control and evaluation of the effectiveness of family doctors should be based on clearly defined criteria. Nowadays, each head of the institution could set their own requirements for the effectiveness of medical staff.

The main purpose of introducing criteria for evaluating the effectiveness of the family doctor is to analyze the diagnostic, treatment, prevention, and organizational work of the family doctor to improve the quality of primary health care and monitor the health of the contracted population.

The main medical records in assessing the effectiveness of the family doctor should be the ambulatory medical record; child's record; passport of the medical department of family medical practice; slip for an outpatient in a general practice institution - family medicine; statement of patient visits; control card of dispensary observation, etc.

When assessing the family doctor's effectiveness, it is recommended to use the criteria for determining the effectiveness of his work separately for adults and children and with the help of women during pregnancy. The following indicators should be considered when providing outpatient care to the adult population:

- stabilizing or reducing the level of hospitalization of the catchment population;

- reducing the frequency of ambulance calls to the catchment population;

- increase in the number of visits to the catchment population of the medical treatment and preventive care institution for preventive purposes, completeness of coverage of medical and preventive care of persons under dispensary supervision;

- completeness of coverage of preventive vaccinations of the attached population;

- stabilizing or reducing mortality at home with cardiovascular disease, tuberculosis, diabetes;

- the number of under 60-years-old died at home for the circulatory diseases and who weren't observed during the last year of life

- $\quad$ stabilizing the incidence of social diseases such as tuberculosis, hypertension, diabetes, cancer;

- the validity of the appointment of drugs and compliance with the rules of prescribing to patients, etc.

In the process of providing outpatient care to children, it is essential to consider several indicators as follows: preventive activities of the family physicians among the child population; complete nursing of oneyear-old children; full coverage of preventive examinations of children; the share of one-year-old children who are breastfeeding; no deaths of children at home, including one-year-old children; no cases of daily mortality of children in the hospital, including one-year-old children.

The effectiveness of the family physician providing outpatient care to women during pregnancy is assessed by the absence of the following cases: antenatal fetal death; congenital malformations undetected during pregnancy; uterine rupture before hospitalization; untimely hospitalization for preeclampsia of moderate severity; untimely hospitalization during a delayed pregnancy.

The specification of specific indicators for assessing the effectiveness of the family physician is determined by the head of the healthcare institution, considering the number, density, age, and sex of the population, morbidity, geographical, and other features. If necessary, according to the decision of the head of the health care institution, additional indicators for evaluating the effectiveness of the family physician may be used. It stands to note that the lack of uniform requirements for administrative control and evaluation of the work of family physicians complicates the process of administering the work of primary care physicians. Those mentioned above should be addressed.

Besides, the practice of administering family physicians covers the problems as follows:

- outdated material and technical support;

- insufficient material and technical base;

- $\quad$ aging family physicians; 
- reduced prestige of the specialty «Family physician»;

- the psychological difficulties of the family physicians while restructuring their practice and mastering modern information and digital technologies;

- difficulties with electronic patient registration;

- lack of full and quality access to the Internet;

- $\quad$ problems in accessing electronic medical records in the eHealth system;

- insufficient provision of vehicles for visiting the population at home;

- $\quad$ weak preventive and educational orientation of family physicians, etc.

Therefore, the mentioned above problems of administering family physicians in Ukraine require attention and solutions from the government and the administration of primary health care facilities.

Validity of effectiveness of family physicians administration. Various regulations essentially regulate the provision of primary health care in modern conditions. Thus, there are numerous mandatory instructions, regulations, orders that provide a particular method of diagnosis, treatment, prevention and are usually by-laws. The primary care unit has been reformed. In turn, the family physicians have found themselves in a new environment.

Therefore, this study surveys family physicians to determine the effectiveness of reforming primary care and their attitude to new working conditions. This survey was conducted on the following questions:

1. Has it been easy for you to get a position as a family physician?

2. Did the constitution of contracts with the population cause difficulties?

3. Were you able to conclude the required number of contracts in less than 6 months?

4. Was it difficult to master the digital technologies necessary for your work?

5. In your opinion, has the administration of your work improved by the management?

6 . In general, do you positively assess the primary level's reform?

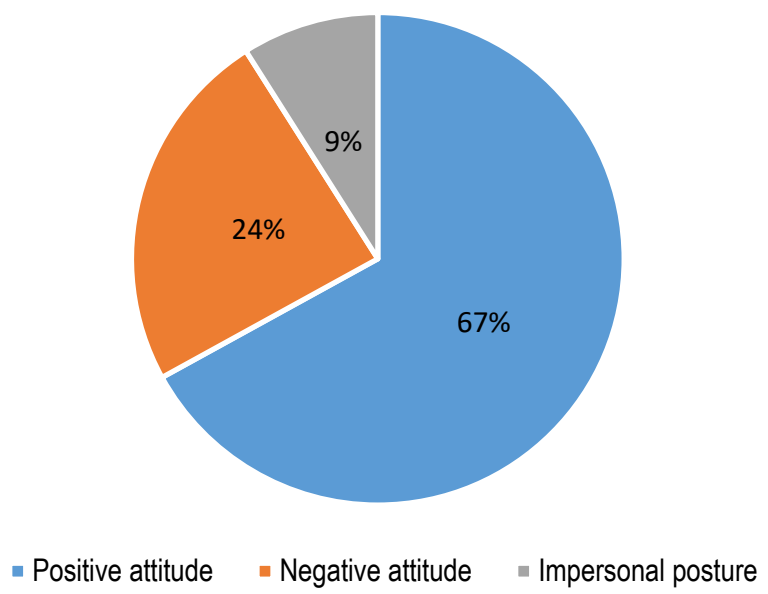

Figure 5. The attitude of the family physicians of Konotop Hospital to the reform of primary care Sources: developed by the authors based on the internal documentation.

The respondents could choose the «yes», «no», or «difficult» answers. Figure 5 presents the results of the survey.

The obtained results indicated that family physicians had a positive attitude to primary health care reform $(67 \%)$. In turn, $24 \%$ of respondents had a negative attitude to the new treatment approach in 
primary health care. It is difficult for them to master the digital technologies necessary for work and to constitute the contract determined by the state for 6 months. Furthermore, $9 \%$ of respondents neither agree nor disagree.

In addition, this study determined the attitude of family physicians to the system of administration of their work. This survey was conducted on the following questions:

1. How do you feel about the work of the administration?

2. Are you satisfied with the administrative activities of the management?

3. Did the reforms positively affect the work of the administration?

4. Do you think it is necessary to choose another model of family doctor administration?

5. What is your attitude to separating functions between the director and the medical director (deputy medical officer)?

Respondents could choose «positive»/«yes», «negative»/«no», «impersonal»/«l do not know» answers. Figure 6 presents the results of this survey.

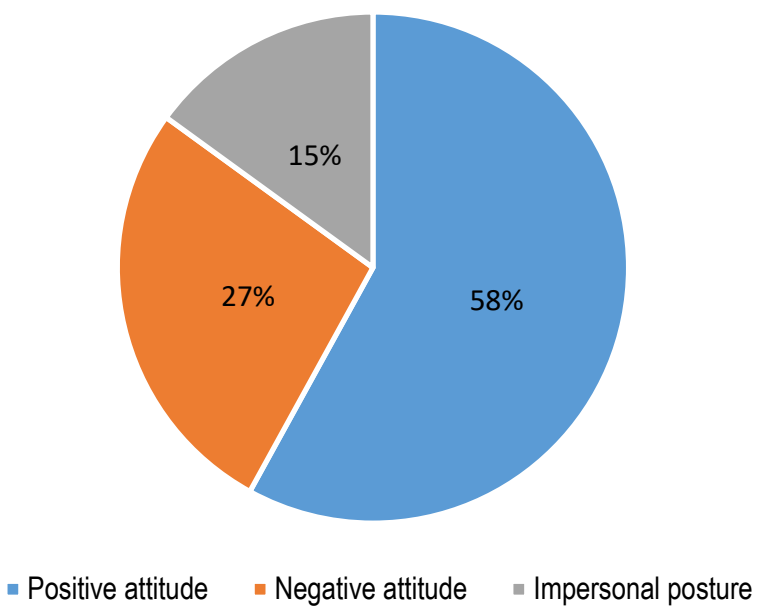

Figure 6. The family physicians' attitude to the process of administration in the hospital Sources: developed by the authors based on the internal documentation.

The survey findings showed that most respondents $(58 \%)$ had a positive attitude to the administration process and the work of administration. Besides, $27 \%$ of respondents had a negative attitude to the administration and administration of their work activities. They believed that the reform of administrative activities in healthcare facilities had undesirable consequences for their work. $15 \%$ of respondents have an impersonal posture to administrative activities in a healthcare facility.

For testing the effectiveness of family physicians' administration in the new working conditions (after the reform of primary care), this study employed the comparative statistical analysis of their work according to the defined criteria. The study covers 2017 and 2019 (before and after the primary health care reform). Because 2018 is a transitional year, it was not chosen for analysis. This process could cause inaccuracy of the results obtained due to the dynamic transition process from the outdated to the modern system of family doctors.

The evaluation of the family physicians' effectiveness was carried out from the administrative point of view. Besides, it was based on the verification of basic medical records, such as medical records of outpatients; child's records; passport of the medical department of family medical practice; slip for an 
outpatient in a general practice institution - family medicine; statement of patient visits; control card of dispensary observation, etc.

As a result of checking medical records over the years, it was noted that the introduction of electronic medical records has greatly facilitated the work of family physicians and increased their productivity. This reform made it possible to quickly keep records of visits to the family physicians by patients and assess the child's development on the child's record. Due to the electronic medical records, the analysis of the condition of patients, the dynamics of chronic diseases development, if any, was significantly accelerated. Connecting the family physician with specialized doctors has become more productive. Thus, it caused positive changes in medical records, and as a result, facilitated the control and administration of family physicians.

Table 2 presents the results of the validity of the effectiveness of family physicians in the Konotop Hospital. After the reform, positive changes in the work of family physicians were noted, such as reducing the catchment population's number of hospitalizations and ambulance calls; mortality at home from cardiovascular disease, tuberculosis, diabetes. In turn, there was an increase in visits to the catchment population of the healthcare facility for preventive purposes. In addition, the number of children increased in the first year of life covered by nursing, an increase in the number of preventive examinations of children, the absence of deaths at home. There was a decrease in congenital anomalies in the development of children not detected during their mothers' pregnancy. In general, the results show a positive trend in the work of family physicians and their closer interaction with their patients.

For identifying difficulties in the family physicians' work, a conversation with primary care managers and medical staff was conducted. They indicated the factors that complicate the process of administrative work in the medical institution. Conventionally, according to the method of occurrence, these factors could be divided into two groups such as environmental factors and internal environmental factors. In turn, environmental factors include:

- from the state: inflated licensing requirements; high requirements for medical facilities; outdated standards of equipment for medical inspection rooms, etc.;

- from suppliers: inflated cost of medical materials and equipment;

- on the part of consumers: high level of distrust in medicine, the biased attitude of the population to free medical services;

- other factors: problems of premises, etc.

On the other hand, the factors of the internal environment include:

- low level of diagnostic services;

- lack of advertising and marketing (or their low quality);

- low administrative and managerial qualification of managers of institutions; shortage of qualified medical personnel;

- shortage of financial resources and underfunding.

In total, interacting with each other, these factors inhibit the development of modern medicine. Thus, the main problems that arise in the management of medical institutions at the present stage are as follows:

- underfunding;

- low level of trust of Ukrainian citizens in the health care system;

- problems of quality and availability of medical services;

- highly qualified medical personnel shortage.

- low managerial qualification of heads of health care organizations. 
Table 2. Comparison of the effectiveness of family physicians' work in 2017 and 2019

\begin{tabular}{lcc}
\hline \multicolumn{1}{c}{ Indicators } & $\mathbf{2 0 1 7}$ & $\mathbf{2 0 1 9}$ \\
& \multicolumn{2}{c}{ persons } \\
\hline the number of the catchment population hospitalization & 5721 & 3956 \\
the number of ambulance calls to the catchment population & 3465 & 2928 \\
the number of visits to the catchment population of the medical treatment and preventive & 217 & 681 \\
care institution for preventive purposes & & \\
medical and preventive care of persons under dispensary supervision & 97 & 243 \\
preventive vaccinations of the attached population & 3657 & 7824 \\
mortality at home with cardiovascular disease, tuberculosis, diabetes & 231 & 129 \\
the number of under 60-years-old died at home fro the circulatory diseases and who & & 103 \\
weren't observed during the last year of life & 279 & 1910 \\
the incidence of social diseases (tuberculosis, hypertension, diabetes, cancer, etc.) & 1754 & 172 \\
the number of ambulance calls by the catchment population & 164 & 512 \\
the number of one-year-old children covered by nursing & 348 & 172 \\
the number of preventive examinations of children & 164 & - \\
the number of one-year-old children who are breastfeeding & 2 & - \\
the number of deaths of children at home, including one-year-old children & 6 & 1 \\
the number of cases of daily mortality of children in the hospital, including one-year-old & 7 & 19 \\
children & & - \\
antenatal fetal death & 24 & - \\
congenital malformations not detected during pregnancy & - & - \\
uterine rupture before hospitalization & 3 & 3956 \\
untimely hospitalization for preeclampsia of moderate severity & 5721 & \\
untimely hospitalization during a delayed pregnancy & &
\end{tabular}

Sources: developed by the authors based on the internal documentation of Municipal non-profit enterprise of Konotop City Council «Konotop Municipal Hospital». follows:

During the conversation, the medical staff mentioned several difficulties, which were summarized as

- absence of the Konotop Municipal Hospital website;

- lack of a single hospital digital system;

- insufficient material and technical support;

- insufficient practical training of young specialists;

- insufficient automation of statistical accounting of family physicians;

- expanding the functional responsibilities of family physicians and insufficient time for their retraining;

- insufficient number of practicing family physicians;

- dissatisfaction with wages;

- difficulties in transiting the paper documents to digital;

- difficulties in visiting the difficult patients at home;

- discrepancy between the responsibilities and powers of family doctors;

- dissatisfaction with the moral stimulation of family physicians;

- the intense psycho-emotional atmosphere in healthcare facilities;

- the problem of architectural accessibility and the need for the aesthetic appearance of the institution. 
Therefore, based on the mentioned above, for ensuring the effective functioning of Ukrainian primary healthcare facilities, the main factors that need consideration are as follows:

- improving the administrative system to ensure better free medical care to citizens (under government guarantee);

- improving the level and quality of material and technical support of the primary level;

- providing healthcare facilities with a sufficient number of highly qualified medical specialists, in particular, family physicians;

- resource provision and infrastructure development of health care institutions using innovative approaches.

Conclusions. The study provides analyzes of family physicians' administration. The findings showed that the administration of medical staff is an essential component of the practice of the healthcare facility. It ensures its successful operation, coordinates the institution's work, creates a strong team, improves the quality of medical services, etc. The central administration models in family physicians' work are determined with traditional care in outpatient clinics, disease control programs, human-centered primary care.

According to the findings, the «human-oriented health care» model is formed in Ukraine. It is evidenced by the changes in the primary family physicians' work. Thus, these changes point to the successful path of the Ukrainian healthcare system towards modernization and European integration.

It is noted that the administration of family physicians has to meet many factors. Evaluating their effectiveness requires considering three main criteria: the significance of work with the adult population, efficiency of work with the child population, and efficiency of working with women during pregnancy.

Furthermore, the reformation of healthcare showed positive changes in the work of family physicians. Thus, there was a reduction in the number of hospitalization and mortality at home from cardiovascular disease, tuberculosis, diabetes; congenital malformations of children not detected during their mothers' pregnancy. On the other hand, there was the growth of visits to healthcare institutions for preventive purposes; no deaths at home, etc. In general, the obtained results indicate a positive trend in the work of family physicians and their closer interaction with patients.

However, the problems identified during the study need to be addressed by the administration of the healthcare institution. The most significant of them is the lack of a website of the Konotop City Hospital; an insufficient number of practicing family doctors; dissatisfaction with wages; difficulties in the transition from working with paper documents to digital; insufficient level of logistics; insufficient level of practical training of young specialists, etc. This study provided general recommendations to the administration and family doctors to improve the administration process.

Author Contributions: conceptualization, S. P. and J. N.; methodology, S. P. and M. G.; validation S. P; formal analysis, J. N.; investigation, S. P. and J. N.; resources, M. G; data curation, S. P.; writingoriginal draft preparation, J. N.; writing-review and editing, S. P.; visualization, S. P.; supervision, S. P.

Funding: This research received no external funding.

\section{References}

Abrams, K. J., Learmonth, S., \& Gibson, C. J. (2017). The Canadian Health Information Management Lifecycle Retrieved from [Link]

Apaydin, E. (2020). Administrative Work and Job Role Beliefs in Primary Care Physicians: An Analysis of Semi-Structured Interviews. SAGE Open, 10(1). [Google Scholar]

Bayeva, O. V. (2007). Basics of health management. Kyyiv, MAUP, 328. [Google Scholar]

Bayeva, O. V., \& Novalska, N. I. (2017). Management and administration. Kyiv, DP «Publisher «Personal», 326.

Bayeva, O. V., \& Radysha, Ya. F. (2008). Medical management: Conceptual and terminological dictionary. Kyiv, Personnel Publishing House, 212. 


\section{S., Pokhylko, M., Grabowska, Yu., Nikitin. Necessary Transformation of Administration for Family Physicians Practice}

Bilynska, M. M., \& Popchenko, T. P. (2017). Development of intellectual and personnel management in public administration of health care. Head doctor, 11(79), 69-73. [Google Scholar]

Danko, V. V. (2017). Management of health care institutions in modern conditions: theoretical aspect. The bulletin of the Kharkiv National Agricultural University of V. V. Dokuchaeva. Economic Science Series, 4, 225-233. [Google Scholar]

Danyuk, V. M. (2013). Personal management. Kyiv, KNEU, 666

De Maeseneer, J. (2017). Family medicine and primary care. At the Crossroads of Societal Change, 1. [Google Scholar]

Decyk, O. Z. (2013). Educational level of heads of health care institutions on health care quality management. Galician Medical Journal, 20, 1(1), 118-120

Didenko, V. M. (2008). Management. Kyiv: Kondor, 584 p.

Dmytruk, O. V., Scinycka, O. M. (2018). Management of adaptation of health protection establishments' staff in the new business environment. Pryazovskyi economic herald, 5(10), 182-186. [Google Scholar]

Doroshenko,G. O. (2015). Management. Kharkiv : «VSV-Print», 300

Dutkevych, T. V. (2005). Conflictology with the basics of management psychology. Kyiv, Center for Educational Literature, 455. [Google Scholar]

Fedorenko, V. G. (2015). Management. Kyiv: Alerta, 492 p.

Grabovskiy, V. A., \& Klymenko, P. M. (2014). Systematic Approach to the Management of Health Care Institutions. Bulletin of the National Academy of Public Administration under the President of Ukraine, 3, 136-142. [Google Scholar]

Hashim, M. J. (2016). Principles of family medicine and general practice-defining the five core values of the specialty. Journal of primary health care, 8(4), 283-287. [Google Scholar] [CrossRef]

Korolenko, V. V., \& Yurochko, T. P. (2018). Personnel policy in the field of health care in Ukraine in the context of European integration. Kyiv, KIM, 96. [Google Scholar]

Kumar, R. (2013). Role of Family Physicians in Healthcare System. Retrieved from [Link]

Love, J. S., Wright, A., Simon, S. R., Jenter, C. A., Soran, C. S., Volk, L. A., ... \& Poon, E. G. (2012). Are physicians' perceptions of healthcare quality and practice satisfaction affected by errors associated with electronic health record use?. Journal of the American Medical Informatics Association, 19(4), 610-614. [Google Scholar] [CrossRef]

Low of Ukraine "Fundamentals of the Legislation of Ukraine on Health Care". Retrieved from: [Link]

Markova, S. V., \& Oliynyk, O. M. (2013). Personnel management. Zaporizhzhia: 3HY, 80.

Mukhambekov, M. M. (2012). Management in healthcare. Moskva: RUDN, 372.

Nagayev, V. M. (2018). Public administration. Kharkiv : XHAY, 278.

Nazarko, S. O. (2020). Effective management of the medical institution in the context of health care reform. Retrieved from: [Link]

Pariy, V. D. (2015). Economic analysis of resource use in the health care system. Zhytomyr, "Polissya», 148. [Google Scholar]

Prokopec, L. V., \& Todoriko, I. M. (2020). Personnel management in health care facilities. Market Infrastructure, 42, 267 -272.

Quinn, M. A., Wilcox, A., Orav, J., Bates, D. W., \& Simon, S. R. (2009). The relationship between perceived practice quality and quality improvement activities and physician practice dissatisfaction, professional isolation, and work-life stress. Medical care, 924928. [Google Scholar]

Rakel, D., \& Rakel, R. E. (2015). Textbook of Family Medicine. 9 th ed. Elsevier Health Sciences; 2015. 1447 p. Retrieved from [Link]

Rovenska, V. V., \& Sarzhevska, Ye. O. (2019). Personnel management of health care institutions in the new economic conditions and prospects for development in Ukraine. Economic Bulletin of Donbass, 3(57), 162-168. [Google Scholar]

Saphonov, Yu. M., \& Borsch, V. I. (2019). Basic principles and features of healthcare strategic Management: a case of Ukrainian health care. Economics and management of the national economy, 8 (218), 62-69.

Shevchenko, R. A., Matushak, A. V, \& Denisenko, Ya. (2017). Medical management in emergency medicine as a guarantee of system efficiency. Emergency medicine: from science to practice, 4 (25), 23-33. [Google Scholar]

Shevchenko, V.A. (2016). Foreign experience in managing health care facilities. Economic Bulletin of the Zaporizhia State Engineering Academy, 6 (2), 9-13. [Google Scholar]

Shupa, L. Z. (2018). Management in insurance medicine. Investments: Practice and Experience, (14), 34-36.

Smiyanov, V. A., Stepanenko, A. V., Petrenko, V. Yu., \& Tarasenko, S. V. (2013). Organizational and methodological approach of medical care quality management in health care facility. Bulletin of Social Hygiene and Health Protection Organization of Ukraine 3, 11-18.

Stephanyshyn, L. C. (2019). Theoretical and methodological bases of strategic management by the health protection body. Market infrastructure, 30, 77-83.

Tretiak, O. P. (2014). Role of Management of Staff in the Formation and Use of the Labor Potential of Medical Institutions. Business Inform, 11, 331-336. [Google Scholar]

Vasylenko, V. A., \& Shostka, V. I. (2003). Situational management. Kyiv.Retrieved from [Link]

Vezhnovec, T. A. (2012). Peculiarities of making administrative decisions by managers of healthcare establishments with different leadership experience. Clinical pharmacy, pharmacotherapy and medical standardization, 4, 138-143.

Voronenko, Yu. V. (2015). New technologies of management training in medicine. Kyiv: Knyga plus, 419 . [Google Scholar]

Health Economics and Management Review, 2021, Issue 3

http://armgpublishing.sumdu.edu.ua/journals/hem 


\section{S., Pokhylko, M., Grabowska, Yu., Nikitin. Necessary Transformation of Administration for Family Physicians Practice}

Voronenko, Yu. V., \& Pashchenko, V. M. (2011). Financial management with the basics of health economics. Kyiv, Interregional Publishing Center «Medinform», 499. [Google Scholar]

Vynogradskiy, M. D., \& Shkanova, O. M. (2009). Personal management. Kyiv. CLL, 500 .

WHO. (1998). Framework for professional and administrative development of general practice/ family medicine in Europe. Retrieved from [Link]

WHO. (n.d.). Primary health care. Retrieved from [Link]

Yeroshkina, T. V., Tatarovskiy O. P., Polishko, T. M., \& Borysenko, S. S. (2012). Fundamentals of management and marketing in medicine. Dnipropetrovsk RVV DNU, 64.

Світлана Похилько, к.е.н., доцент, Сумський державний університет, Україна

Моніка Грабовська, Ph.D., Вроцлавський університет економіки та бізнесу, Польща

Юрій Нікітін, Сумський державний університет, Україна

Необхідні трансформації адміністрування роботи сімейних лікарів

у статті розглянуто головні моделі адміністрування у роботі сімейних лікарів, а саме: традиційне надання допомоги в амбулаторно-поліклінічних установах; програма боротьби з хворобами; первинна медична допомога, орієнтована на людину. Автори відмітили, що в Україні впевнено формується модель «медичної допомоги, орієнтованої на людину», про що свідчать зміни в процесах роботи сімейних лікарів первинної ланки. Ці зміни вказують на ефективність української політики щодо модернізації системи охорони здоров'я та ії інтеграції до європейської. Авторами зазначено скорочення кількості госпіталізацій прикріпленого населення; смертності населення вдома від серцево-судинних захворювань, туберкульозу, иукрового діабету; вроджених аномалій розвитку дітей, не виявлених під час вагітності їх матерів. Наголошено на зростанні кількості візитів прикріпленого населення до медичного закладу з ціллю профрілактики, зростання кількості дітей першого року життя, охоплених патронажем, відсутність випадків смертності дітей вдома тощо. Автори зазначили, що процес адміністративного контролю та оцінка ефективності роботи сімейних лікарів має відбуватися за чітко визначеними критеріями. Наразі кожен керівник установи може встановлювати свої вимоги до ефрективності роботи лікарів первинної ланки. Конкретизація визначених показників оцінювання ефекттивності діяльності сімейного лікаря відбувається з урахуванням кількості, шільності, віковостатевого складу населення, рівня захворюваності, географічних та інших особливостей. Однак відсутність єдиних вимог до адміністративного контролю та оцінки роботи сімейних лікарів ускладнює процес адміністрування роботи лікарів первинної ланки, що потребує подальшого вирішення. Мета статті полягає в аналізі ефективності адміністрування роботи сімейних лікарів у КНП КМР «Конотопська міська лікарня». Авторами висвітлено основні проблеми та напрямки підвищення ефективності адміністрування роботи сімейних лікарів. Встановлено, що найбільш істотними недоліками є відсутність сайту КНП КМР «Конотопська міська лікарня»; недостатня кількість практикуючих сімейних лікарів; незадоволеність заробітною платою; недостатній рівень матеріально-технічного забезпечення недостатній рівень практичної підготовки молодих спеціалістів тощо. При цьому сімейні лікарі відмітили складнощі у переході від роботи з паперовими документами до цифррових; слабкий інтернет та погану роботу відповідних серверів, що впливає на весь процес діяльності сімейних лікарів від моменту запису на прийом до сімейного лікаря через Інтернет або за телефоном до видачі електронних рецептів на ліки чи лікарняних листів. За результатами дослідження сформовано низку рекомендації сімейним лікарям та адміністрації лікарні щодо підвищення ефективності роботи.

Ключові слова: адміністрування персоналу, первинна ланка, медична допомога, сімейні лікарі, ефективність процесу адміністрування. 